\title{
Maize Marketing Model and Store-Time for Household Income Optimizations in Northern Zone of Tanzania
}

\author{
Jennifer Swai ${ }^{1, ~ *}$, Ernest R. Mbega ${ }^{1}$, Arnold Mushongi ${ }^{2}$, Agness Ndunguru ${ }^{3}$, \\ Patrick A. Ndakidemi ${ }^{1}$ \\ ${ }^{1}$ The Nelson Mandela African Institution of Science and Technology, School of Life Science and Bio-engineering, Department of Sustainable \\ Agriculture Biodiversity and Ecosystem Management, Arusha, Tanzania \\ ${ }^{2}$ Ministry of Agriculture, Tanzania Agricultural Research Institute-Ilonga, Department of Crop Science, Morogoro, Tanzania \\ ${ }^{3}$ Ministry of Agriculture, Tanzania Agricultural Research Institute-Uyole, Department of Social-economics, Mbeya, Tanzania
}

\section{Email address:}

jenifaswai60@gmail.com (J. Swai), ernest.mbega.nm-aist.ac.tz(E. R. Mbega), Mushongi@yahoo.com (A. Mushongi), agnessndunguru@yahoo.com (A. Ndunguru),Patric.ndakidemi@nm-aist.ac.tz (P. A. Ndakidemi)

${ }^{*}$ Corresponding author

\section{To cite this article:}

Jennifer Swai, Ernest R. Mbega, Arnold Mushongi, Agness Ndunguru, Patrick A. Ndakidemi. Maize Marketing Model and Store-Time for Household Income Optimizations in Northern Zone of Tanzania. International Journal of Agricultural Economics.

Vol. 4, No. 4, 2019, pp. 186-194. doi: 10.11648/j.ijae.20190404.17

Received: March 15, 2019; Accepted: April 22, 2019; Published: July 19, 2019

\begin{abstract}
This study modeled maize marketing model in Northern Zone of Tanzania together with its store-time for household income optimization. The study has been conducted in three regions i.e. Manyara, Arusha and Kilimanjaro in the selected nine Districts basing on their maize production volume i.e. Karatu, Hai, Siha, Arumeru, Mbulu, Hanang, Babati and Moshi rural. Focused Group Discussions (FGD), structured and semi-structured questionnaires were employed as data collection tools. Multivariate Linear Regression Models were developed together with some other statistical inferences so as to draw conclusions on the findings. This study reveals that, $94 \%$ of farmers depend highly on middlemen for marketing their maize grains. There is a significant relationship between maize marketing channels and household income with $P$-value $=0.04$. Average store-time for majority of the respondents $(70 \%)$ was found to be six-months. There was significant different $(P$-value $=0.002)$ between quantity harvested and store-time of maize in Northern Tanzania. From a multivariate regression linear model, it was found that, for household income optimization special attention should be given much on; production cost, storage cost, marketing cost and quantity of maize to be sold with reference to monthly price trend. This study recommends a range of four to seven month maize store-time for household sale and income optimization.
\end{abstract}

Keywords: Storage Structures, Market Channels, Production Cost, Storage Cost, Price Trends

\section{Introduction}

In Tanzania maize provides a number of benefits such as income creation, source of employment and food security. Maize grain forms the basis of the main family meal; the household with no access to maize is said to be food in secured. At the national level, the crop itself contributes about $20 \%$ of the country GDP, over $30 \%$ household income, $60 \%$ of dietary calories and $50 \%$ of protein intake as the staple food [1-3]. Despite the contributions the crop has in the country, its marketing arrangements are not well characterized when compared with some cash crops such as cashew, coffee and cotton. Maize sector receive a lot of state interventions regardless of high private sectors involvement [4]. However, the extent of state interventions in maize marketing and pricing remains a big challenge to policy makers [5].

In addition, [6] reported that, regions located in the border of neighboring countries and developed regions face grain deficit with higher prices and lower volatility. With regards to the law of demand and supply i.e. maize fetch low prices in surplus regions and vise-versa, with reasonable store-time; thus regional price variations become an opportunity for rural farmers to sell their produce. Apparently, the country 
marketing environments are poorly coordinated across time and space i.e. surplus area vs. deficit, thus farmers cannot take advantage of the spatial or short-term arbitrage which results into unreasonable store-time. The situation force rural farmers to depend highly on traders as middlemen with little or no concerns on store-time aspect in the cause of their poor and asymmetric access to market information.

In developing countries, there exists a riddle "sell low and buy high" among smallholder farmers due to improper storage facilities [7, 8]. This riddle assumes that, farmers with little liquidity asset sell grain early during the harvest period at a low price and purchases the same grain later at high price during postharvest period just four to six months later. Normally, debts such as school and other social obligations are generally due soon after harvest. To ensure reasonable store-time, farmers must be able to meet their debts in the harvest season through credit or sufficient personal savings, rather than immediately grains sells so as to cover these obligations. It has been reported by [9] that, storing grains for future sales requires a producer to forego investing postharvest grain sales in other revenue-generating activities that may generate very high rates of return which could very well outpace returns from commodity storage.

Numerous studies in the Sub-Saharan African countries reported that adoption of improved maize varieties contribute to a raising productivity, household income and food security [10-12]. On the contrary, [13] report that higher yielding varieties are more susceptible to storage pests than loweryielding traditional varieties. This justifies that, intensifying grain yield without proper modeling of their marketing environment and store-time may not be the only solution. There are multiple and interacting factors that shape farmers' decisions at postharvest handling and management of maize grain. Food security does not just end at harvest as storage insect pest can cause significant postharvest losses of up to $30 \%$ in six months of storage [14]. Farmer's willingness and ability to store produce definitely defines marketing trend and price variability which are a function of accessibility to appropriate storage practices and full involvement in the market chain in a beneficial way [15].

Maize store-time as a prime factor in grain businesses has attracted little attention in postharvest management studies in most of the developing countries regardless of their potential contribution to marketing models. In most studies, storage losses and technologies are covered in the general storage cost $[16,17,19]$ to the extent that there is no measure of the isolated effect of storage losses so as to bring up suitable storage practices and store-time. Time component in maize postharvest interventions and how it would influence farmers' economic decisions is crucial. One way to describe that is through a marketing model.

In Tanzania there are a number of marketing models that have been described [15]. The common ones are Professional Maize Growers' Associations, Grassroots organizations e.g. Kibaigwa International Grain Market, Warehouse Receipt Systems and Mobile Phone Market Information. Despite reports of these models, the local maize markets have little or no indication of standard prices. The prevailing models do not address some of the maize store-time challenges such as; the relationship between storage cost and total farmer income, the recommended amount of maize to be stored with regards to maximum profitability, recommended selling price after storage, the established maximum level of postharvest loss, and recommended storage practices for quality maize.

This study offers suggestion to monitor further debates on the link between maize marketing model and their store-time in justifying small-holders farmer's household income optimizations in Northern Zone of Tanzania, pin-pointing operating maize trade flows and their marketing channels, to estimate household income with regards to store-time in relation to monthly price trend. This article reviews several practical operating maize marketing channels with marketing model and the prevailing maize store-time in Northern Zone of Tanzania. Hence, we argue that extra insights should be geared towards clear match between maize marketing models and appropriate store-time for future agricultural development and poverty reduction. To make our points, we review and in some cases present new empirical evidence from small-scale farm household survey in Northern zone specifically Arusha, Kilimanjaro and Manyara regions.

\section{Methodology}

\subsection{Study Site}

This study was conducted in the Northern Zone of Tanzania particularly in Manyara, Arusha and Kilimanjaro regions. Three Districts were purposively chosen in each of the three regions. The Districts by regions include: Manyara (Babati, Hanan'g, and Mbulu), Arusha (Monduli, Arumeru and Karatu), and Kilimanjaro (Siha, Hai and Moshi rural). The Districts were selected due to the fact that they are the major maize growing areas of the north Tanzania, and also based on their production statistics and preference by Taking Maize Agronomy into Scale in Africa (TAMASA) project which funded this research.

\subsection{Household Sample Selection}

The sampling frame was the maize farming households in the study Districts. Random sampling from 10x10km grids was established in the study Districts based on GPS coordinates. From each $10 \mathrm{mx} 10 \mathrm{~m}$ grid, three $1 \mathrm{~km} \times 1 \mathrm{~km}$ grids were randomly selected. In each of this $1 \mathrm{~km} \times 1 \mathrm{~km}$ grids 12 households were randomly selected for enumeration. A survey included 270 households ( 30 households from each District). The survey was conducted between August 2017 and May 2018. Semi structured questionnaires and focused group discussions were employed as data collection tools. From each village, eight household from the interviewed households were randomly selected from each district and monitored for six months consecutively (Nov-April) on the employed marketing chain, marketing model, marketing cost, storage cost, price trends with their respective maize grain sales volumes, store-time. Furthermore, their results are well 
presented in this article. Together with their traditional storage facilities, the selected households were provided with PICS bag as one of the improved storage facility to establish clear link between store-time and access to storage structures. To complement the structured questionnaire employed, focus group discussions were conducted, with an involvement of all necessary maize marketing chain actors and extension staffs from nine selected districts to get in-depth qualitative information.

\subsection{Sample and Sampling Procedures}

This study involved different maize marketing chain actors in the selected areas. The selected households were voluntarily subjected into six-month maize store-time consecutively. Monthly maize price trends together with their sales volumes in relation to transaction costs were clearly observed to establish clear link between store-time and gained household income.

\subsection{Data Collection}

This study employed primary data through household semi-structured interviews and focus group discussions as main survey tools, with an involvement of relatively large traders, small traders in rural areas, rural maize processors, government actors, and others necessary actors in the operating maize value chain in Manyara, Arusha and Kilimanjaro regions. Within each village, 10-15 farmers were selected to participate in the focus group discussion. These farmers were selected as they self-identified as maize growers who sold maize during the previous marketing season. The main focuses of data collection were on the structure, conduct, and performance of the maize marketing models and their store-time basing on an individual's experiences and business operations. Additionally, data were collected about individual farmer's maize sales, the timing of these sales and marketing channels. Furthermore, monthly maize prices trends were collected from the district and village market centers, also data on maize trade environment were collected from the selected key informant's interviews within the village.

\subsection{Data Analysis}

Data were entered into an Excel 2010 spreadsheet, later on SPSS and R statistical software version 3.5.1 were employed as data analysis tools whereby important statistical parameters such as, descriptive statistics tables, Correlation tests and Multivariate regression models were employed leading into evaluation of maize marketing models, establishing clear relationship between store-time and household income. Furthermore the Multicollinearity and significance of the predictors have been tested basing on Variance Inflation Factor (VIF) for each predictor in the model as suggested by [19]. The conclusions were drawn basing on $P$-values and Coefficient of determinations (R squared), Akaike Information Criteria (AIC). Significant differences in grain losses parameters were concluded basing on the statistical significance levels of their coefficient of the interaction term i. e $P \leq 0.05, P \leq 0.01$, or $P \leq 0.001$.

\section{Results}

\subsection{Household Store-Time in Relation to Demographic Characteristics}

From the chi-square test it has been observed that, two demographic variables were found to have a significant associations with their store-time which are; household education level with $\chi^{2}(16)=29.31, P$-value $=0.02$ and household head marital status $\chi^{2}(20)=40.33, P$-value $=0.005$ as shown in Table 1.

Table 1. Association between household store-time and demographic characteristics.

\begin{tabular}{lll}
\hline Demographic characteristics & $\boldsymbol{\chi}^{2}$-value & $\boldsymbol{P}$-value \\
\hline Family size & 22.9 & 0.5 \\
Food security & 4.3 & 0.4 \\
Crop sales & 3.9 & 0.4 \\
Total harvest & 20.8 & 0.6 \\
Education level & 29.3 & $0.02^{* *}$ \\
Informal income & 1.2 & 0.9 \\
Marital status & 40.3 & $0.005^{* * *}$ \\
Gender & 0.5 & 0.9 \\
\hline
\end{tabular}

$* * *, * *$ and $*=$ significant at $\mathrm{P} \leq 0.001,0.01$ and 0.05 respectively.

\subsection{Prevailing Storage Structures in the Study Area}

From the results, it has been revealed that the dominant storage structures across the study area were Polyethylene bags without insecticide amounting $62.7 \%$ being the most preferred, Polyethylene bags with Insecticide amounting $15.7 \%$ ranking the second, PICS bags $12.7 \%$, Metal Drum $7.4 \%$ and Kihenge $1.1 \%$ being the least as shown in Table 2.

Table 2. Household storage structures distributions.

\begin{tabular}{ll}
\hline Storage Structures & Percentage \\
\hline Polyethylene bags without insecticide & 62.7 \\
Polyethylene bags with Insecticide & 15.7 \\
PICS bags & 12.7 \\
Kihenge & 1.1 \\
Drum & 7.4 \\
\hline
\end{tabular}

\subsection{Associations Between Storage Cost and Storage Structures}

The results show that there was associations between the household preferred storage structure and the involved storage cost throughout the store-time, whereby Polyethylene bag without insecticide scored a strong coefficient of correlation 0.77 with $P$-value $<0.0001$; Polyethylene bag with insecticide scored coefficient of correlation 0.09 with $P$-value of 0.004 , Metal drum had 0.006 correlations of coefficient and $0.02 P$-value. The PICS bags and Kihenge had insignificant $P$-values with 0.12 and0.04 coefficients of correlation, respectively as presented in Table 3. 
Table 3. Association between maize storage cost and storage structures in Northern zone of Tanzania during 2017/18 cropping season.

\begin{tabular}{|c|c|c|c|c|c|c|}
\hline Variables & PICS bags & Polyethylene 1 & Kihenge & Metal drum & Polyethylene 2 & Storage cost \\
\hline PICS bags & 1 & & & & & \\
\hline Polyethylene 1 & 0.29 & 1 & & & & \\
\hline Kihenge & -0.03 & -0.1 & 1 & & & \\
\hline Metal drum & -0.12 & -0.11 & -0.09 & 1 & & \\
\hline Polyethylene 2 & 0.22 & -0.14 & -0.03 & -0.09 & 1 & \\
\hline Storage cost & 0.12 & 0.77 & -0.04 & 0.06 & 0.09 & 1 \\
\hline$P$-values & 0.5 & $<0.1 \mathrm{e}^{-4^{* * *}}$ & 0.4 & $0.02 *$ & $0.004 * *$ & \\
\hline
\end{tabular}

$* * *, * *$ and $*=$ significant at $\mathrm{P} \leq 0.001,0.01$ and 0.05 respectively. Polyethylene $1=$ Polyethylene bags without insecticide, Polyethylene $2=$ Polyethylene bags with insecticide.

\subsection{Association Between Store-Time and Storage Structure}

The results showed that there was a significant association between store time and storage structures especially on Polyethylene bags with insecticide, with a coefficient of correlation of $0.23, P$-value 0.05 ; Metal drum had a coefficient of correlation 0.17 with $P$-value of 0.03 ,
Polyethylene bags without insecticide scored a coefficient of correlation of 0.14 with $P$-value 0.04 . However, there were no significant associations between store time and PICS bags as well as Kihenge regardless of its positive coefficient of correlations of 0.19 and 0.07 respectively (Table 4).

Table 4. Association between store time and storage structures in Northern zone of Tanzania during 2017/18 cropping season.

\begin{tabular}{|c|c|c|c|c|c|c|}
\hline Variables & PICS Bags & Polyethylene 1 & Kihenge & Drums & Polyethylene 2 & Store time \\
\hline PICS Bags & 1 & & & & & \\
\hline Polyethylene 1 & 0.29 & 1 & & & & \\
\hline Kihenge & 0.03 & -0.10 & 1 & & & \\
\hline Drums & -0.12 & -0.11 & -0.09 & 1 & & \\
\hline Polyethylene 2 & -0.23 & -0.15 & -0.03 & -0.09 & 1 & \\
\hline Store time & 0.19 & 0.23 & 0.07 & 0.17 & 0.14 & 1 \\
\hline$P$-values & 0.11 & $0.05 *$ & 0.3 & $0.03 *$ & $0.04 *$ & \\
\hline
\end{tabular}

$* * *, * *$ and $*=$ significant at $\mathrm{P} \leq 0.001,0.01$ and 0.05 respectively. Polyethylene $1=$ Polyethylene bags without insecticide, Polyethylene $2=$ Polyethylene bags with insecticide.

\subsection{Maize Price Trends Between 2016/17 and 2017/18}

Three months maize price trends i.e. May, February and December between 2016/17 and 2017/18 in the study regions were collected to assess the associations between household income and store-time with regards to the prevailing price. It was observed that, there were prices differences between two cropping seasons whereby maize prices in 2016/17 season were higher compared with 2017/18. Furthermore, 52\% of the respondents depend highly on the middlemen as a source of price information, the rest $48 \%$ depends on their neighbours. However, there was no significant relationship between the quantity of maize sold in the household and the accessibility to price trends information with $P$-value: 0.556 and Adjusted R-squared-0.0127 (Table 5).

Table 5. Maize price trends information.

\begin{tabular}{|c|c|c|c|c|}
\hline Variable & Estimates & std Error & t-value & $P$-value \\
\hline Intercept & 1.03333 & 0.02262 & 45.691 & $<2 \mathrm{e}-16 * * *$ \\
\hline Price information (Neighbour) & 0.03333 & 0.3148 & -1.059 & 0.294 \\
\hline Price information (Middlemen) & 0.03333 & 0.06595 & -0.506 & 0.615 \\
\hline
\end{tabular}

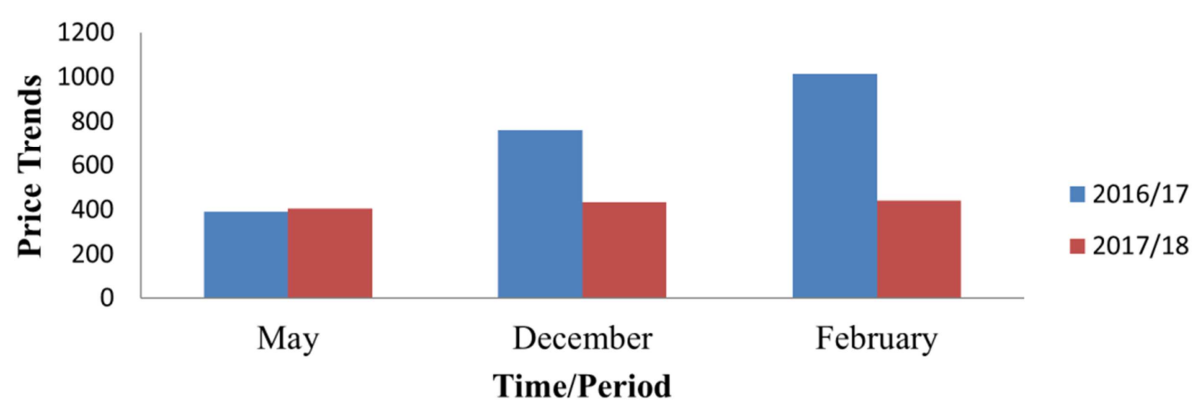

Figure 1. Maize price trends during 2016/17 and 2017/18 cropping seasons on Northern zone of Tanzania.

\subsection{Household Store-Time}

The average store-time for the majority of the respondents
(Figure 2) were six months $(70 \%)$; five months $(8 \%)$; four months $(15 \%)$, three months $(6 \%)$ and one month $(1 \%)$. 
Furthermore, from the correlation test, it was observed that there was significant difference between quantity harvested and store-time with $P$-value $=0.002245$ and coefficient of correlation $=0.3697753$. Furthermore, there was a significant correlation between store-time and expected profit generated by the household with $P$-value of 0.0285 , coefficient of correlation of 0.3 Table 6 .

Table 6. Household store-time and quantity harvested.

\begin{tabular}{llll}
\hline Variable & Coefficient of correlation & Df & t-value \\
\hline Qharvested and store time & 0.3877695 & 64 & 3.3655 \\
Qharvested and stored & 0.9744322 & 64 & 0.001296 \\
\hline
\end{tabular}

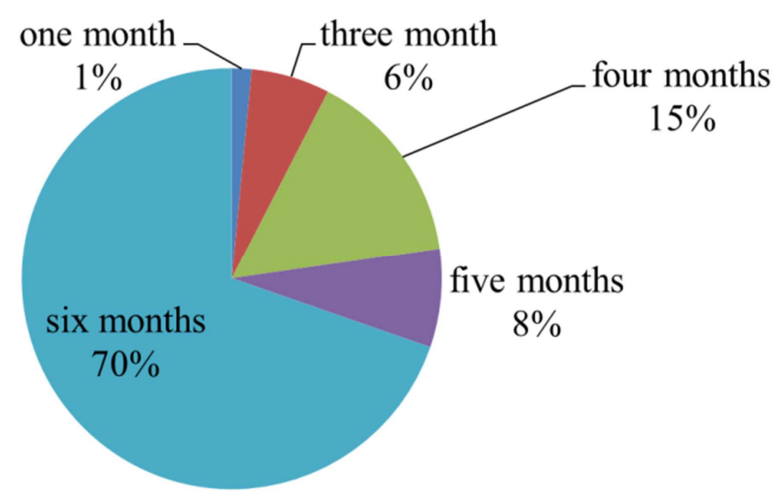

Figure 2. Household maize store-time in the Northern Zone of Tanzania during the 2017/18 cropping season.

\subsection{Prevailing Marketing Channel Along Maize Marketing Model}

The results show that, there were maximum interactions between the majority of households and village grain assemblers as a crucial aspect of the maize marketing chain (Figure 3). Despite the observed differences between farmget price and market price of an average of $5000 \mathrm{Tsh} / 100 \mathrm{~kg}$, yet, farmers depend highly on middlemen as a direct source of the market, about $94 \%$ of the respondent's sale their maize direct to village assemblers while only $6 \%$ sale their maize grains direct to the market (Table 1). Furthermore, there was a significant relationship between marketing channels and income gained by household with $P$-value $=0.01$, and Adjusted R-squared of 0.04817 Table 7 .

Table 7. Marketing channels along maize marketing model.

\begin{tabular}{|c|c|c|c|c|}
\hline Variable & Estimates & std Error & t-value & p-value \\
\hline Intercept & 2271000 & 521688 & 4.353 & $4.94 \mathrm{e}-05 * * *$ \\
\hline Price information (Neighbour) & -1341569 & 538254 & -2.492 & $0.0153 *$ \\
\hline
\end{tabular}

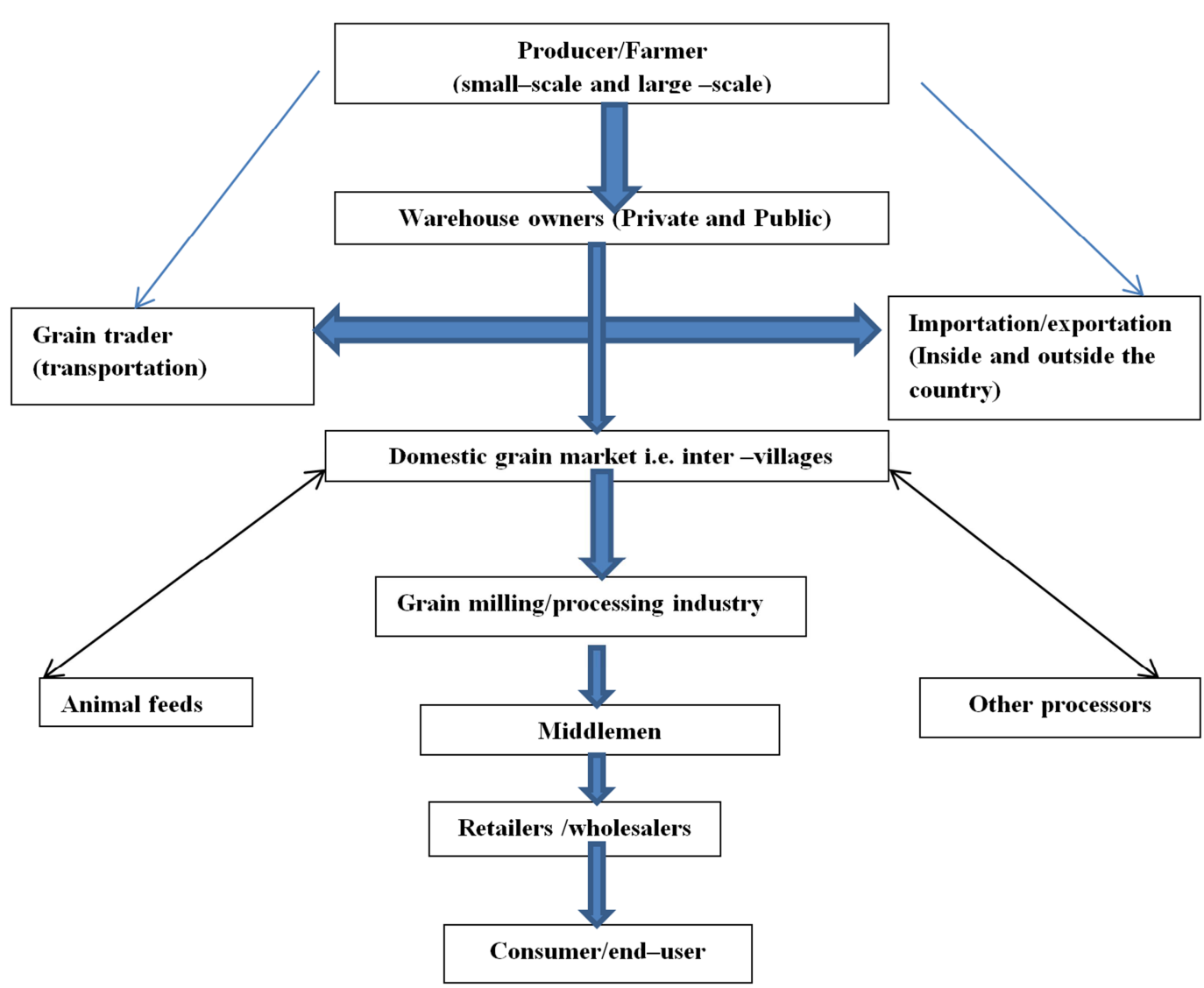

Figure 3. Hypothetical Maize marketing channels in the Northern Zone of Tanzania Source: [20]. 


\subsection{Return on Investment in Relation to Store-Time}

The results for multivariate regression model generated showed that household can optimize their gain after storing maize grain for about five months store -time with highest coefficient of 0.713 and a very significant $P$-value of $<2.2 \mathrm{e}-$ 16. The expected profit gained in January has been removed from the model due to its insignificant AIC value considering regression stepwise model selection algorithms. However, profit gained on August was found to be the least based on its negative coefficient of-225.51 regardless of its significant $P$ value of 0.03296 . With regards to maize price trends, December and April were found to be beneficial sell-time to household income with 451.79, 368.80 coefficients and $0.00776,1.31 \mathrm{e}^{-13} P$-values, respectively. The generated model was best fitted with the AIC of 1719.83, Adjusted Rsquared: 0.7534 and $P$-value of $<2.2 \mathrm{e}-16$ (Table 8 ). The multivariate linear regression model 1 has been generated to show the relationship between variables.

Table 8. Interaction between household income and maize store-time for Northern zone of Tanzania.

\begin{tabular}{|c|c|c|c|c|}
\hline Coefficients & Estimates & Std. Error & t-value & P-value \\
\hline Intercept & -311371.65 & 75123.93 & -4.145 & $0.00011 * * *$ \\
\hline Immediately sales (August) & -225.51 & 103.26 & -2.184 & $0.03296 *$ \\
\hline Three month store-time (November) & 231.20 & 96.85 & 2.387 & $0.02020 *$ \\
\hline Four month store-time (December) & 451.79 & 163.90 & 2.757 & $0.00776 * *$ \\
\hline Five month store-time (February) & 153.90 & 51.40 & 2.994 & $0.00402 * *$ \\
\hline Six months store-time (March) & 318.83 & 107.16 & 2.975 & $0.00424 * *$ \\
\hline Seven months store-time (April) & 368.80 & 38.54 & 9.568 & $1.31 \mathrm{e}^{-13 * * *}$ \\
\hline
\end{tabular}

$* * *$ And $* *=$ significant at $\mathrm{P} \leq 0.001$ and 0.01 respectively, $\mathrm{Y}=$ Income, $\mathrm{X}=$ Predictors, $\mathrm{X}_{\text {August }}=$ immediately sales, $\mathrm{X}_{\mathrm{November}}=$ Three month store - time, $\mathrm{X}_{\text {December }}$

$=$ Four month store - time, $X_{\text {February }}=$ Five month store - time, $X_{\text {March }}=$ Six months store - time and $X_{\text {April }}=$ Seven months store - time

Model 1: $Y_{\text {August, November, December, February, March, April }}=-311371.65-225.51 \mathrm{X}_{\text {August }}+231.20 \mathrm{X}_{\text {November }}-451.79 \mathrm{X}_{\text {December }}+153.90 \mathrm{X}_{\mathrm{February}}+318.83 \mathrm{X}_{\text {March }}+368.80 \mathrm{X}_{\text {April }}+$ C

\subsection{Maize Store-Time Marketing Model on Household Income Maximization}

From the study, maize return to investment was modeled following Multivariate Linear Regression. Later a stepwise regression algorithm was employed for model selection considering multicollinearity and significance of the predictor variables. Generated model was the best fit with
Adjusted R-squared: 0.942, $P$-value $<2.2 \mathrm{e}-16$ and $\mathrm{AIC}=1653.23$ on 8 and 57 degrees of freedom. The significant relationships between household incomes with all selected variables are clearly stipulated in Table 9. The multivariate linear regression model 2 has been generated to show the relationship between variables.

Table 9. Maize Household income optimization model for Northern zone of Tanzania model 2.

\begin{tabular}{|c|c|c|c|c|}
\hline Coefficients & Estimates & Std. Error & t-value & $P$-value \\
\hline Intercept & $-5.575 \mathrm{e}^{05}$ & $2.681 \mathrm{e}^{05}$ & -2.079 & $0.0421 *$ \\
\hline Storage cost & 9.602 & $9.128 \mathrm{e}^{-01}$ & 10.519 & $5.70 \mathrm{e}^{-15 * * *}$ \\
\hline Production cost & 0.4314 & $8.355 \mathrm{e}^{-02}$ & 5.164 & $3.21 \mathrm{e}^{-06} * * *$ \\
\hline Maize sales (December) & $2.564 \mathrm{e}^{02}$ & $9.863 \mathrm{e}^{01}$ & 2.600 & $0.0119 *$ \\
\hline Maize sales (March) & $2.943 \mathrm{e}^{02}$ & $6.619 \mathrm{e}^{01}$ & 4.446 & $4.10 \mathrm{e}-05 * * *$ \\
\hline Maize sales (April) & $1.526 \mathrm{e}^{02}$ & $3.529 \mathrm{e}^{01}$ & 4.326 & $6.19 \mathrm{e}-05 * * *$ \\
\hline Marketing cost & $7.740 \mathrm{e}^{01}$ & $3.617 \mathrm{e}^{01}$ & 2.140 & $0.0367 *$ \\
\hline
\end{tabular}

$* * *$, And $*=$ significant at $\mathrm{P} \leq 0.001$ and 0.05 respectively. $\mathrm{Y}=$ Household income, $\mathrm{X}=$ predictors, $\mathrm{SC}=\mathrm{Storage}$ cost, $\mathrm{PC}=\mathrm{Production}$ cost, Sales $1=$ November Maize sales, Sales2=December Maize sales, Sales3=March maize sales, Sales4= April maize sales, Price= January selling price and MC $=$ Marketing cost.

Model 2: $Y_{\mathrm{SC}, \text { PC, Sales1, Sales2, Sales3, Sales4, Price, } \mathrm{MC}}=-5.575 \mathrm{e}^{05}+9.602 \mathrm{X}_{\mathrm{SC}}+0.4314 \mathrm{X}_{\mathrm{PC}}+2.745 \mathrm{e}^{02} \mathrm{X}_{\text {Sales } 1}+2.564 \mathrm{e}^{02} \mathrm{X}_{\text {Sales2 }}+2.943 \mathrm{e}^{02} \mathrm{X}_{\mathrm{Sales} 3}+1.526 \mathrm{e}^{02} \mathrm{X}_{\text {Sales } 4}+$ $1.397 \mathrm{e}^{03} \mathrm{X}_{\text {Price }}+7.740 \mathrm{e}^{01} \mathrm{X}_{\mathrm{MC}}+\mathrm{C}$

\section{Discussions}

This study find out that, maize store-time varies based on household educational status, as a matter of fact, levels of formal education ensure the ability to acquire, synthesize and apply the information gathered from various sources. Furthermore, education creates a broader network, therefore, reduces information searching cost as well as time is taken to integrate and employ the acquired information for how long to store maize [21]. In additionally, [22] asserted that "well- educated farmers are well talented to integrate information and make use of new technologies due to their less vertical learning curve". Considering the importance of maize storetime, farmer education needs to be given high consideration through awareness creations through making potential use of extension officers.

From the results, the surveyed respondent was diverse in their marital status. Basically, marital status can be taken as family size determinant and hence influences household maize decisions including store time, implying that there is a significant association between maize store-time and 
household head marital status. In the Northern Zone of Tanzania, maize is the main crop produced by majority of the households and hence standing as the most produced staple food in terms of volume and second cash earning crop. With this regards, inner grain storage motive ensures income security to the community. This fact is in line with [23] who also confirmed that maize contributes to per capita energy consumption and incomes, especially in the developing countries. Thus modeling of its storage structure with their respective store-time is of high importance so as to attain its equilibrium price.

Polythene bags without insecticide were found to be the dominant storage structure employed in the study area despite its significant contributions in postharvest losses amounting $43 \%$ These findings are similar to [24] who found that Polythene bags without insecticide was the most common maize storage structure/method found in almost many maize growing locations. Furthermore, there was is a strong correlation between store-time and insect damaged kernels and such observations indicated an increase in maize postharvest losses. [25] Reported a similar result that, Polyethylene bags without insecticide offers tiny defense alongside storage insect pests especially borers in only a short time interval. The observed inefficient is highly associated with Polyethylene bag building materials which are weak in maize grains protection against insects especially borers, also the possibilities of the stored grains to absorb moisture from the floor in case of direct contact resulting into maize rotting.

Basically, selection of storage structure is highly influenced by the storage cost of the specified structure throughout the store-time as shown in a correlation test during this study. Polyethylene bag without insecticide had a strong coefficient of correlation which shows a positive strong association between storage structure and the storage cost. This conclusion is in line with [24] who reported that, farmers are not ready to bear extra cost in the cause of insecticide application. This study has indicated a strong link between store-time and PICS bag. The results are in line with [26] who found that grain held in PICS bags for six month store time were found to have neither weight losses nor grain damage.

This study also showed that there is a significant difference on maize store-time among households basing on the quantity of maize harvested by the household. Using a generated multivariate regression model, a household can optimize their return to investment from five-month storetime with a highest coefficient. In order to maximize household returns to investment as a function of store-time, storage cost, production cost, maize sales on November, and March and maize sales on April are variables with very high significant contributions on household income maximization. Therefore, a slight change in the fore mentioned variables may result in very significant alterations on household income; hence need to be given special attention. However, maize sales on December and maize selling price on January and marketing cost have significant contributions on household income hence a change in these variables reflect a change in household income.

In northern zone of Tanzania, maize marketing channels begins with a large and highly distinguished set of farmers over an equally various group of key assemblers and transporters before reaching other marketing channels actors and finally consumers with an inclusions of exchanges between farmers and consumers as well as small and medium-sized traders to small retailers and consumers. Large amount of maize grains pass through the marketing scheme in the absence of large trading and processing firms. As such, there are many different transaction points within the value chain, many of which overlap and feed into one another until maize reaches to the final consumer whereby most of them are farmers who sold theirs produces soon after harvest (Figure 3).

This study found that, maize middlemen (village grain assemblers) stand as main farmer's market sources and hence affect the interaction between households and urban traders. In this context, the middle man plays a key role in marketing of maize due to high transaction cost in the cause of poor rural transportation infrastructures, and at times the village middlemen in some cases they provide financial assistance to farmers (as reported during Focus Group Discussion). Similar findings have been documented by [27, 28] who revealed that the majority of smallholder's farmers located in remote areas depend highly on village middlemen/brokers.

In additionally, [29] reported that, rises in marketing costs as a result of poorer road infrastructures to the distance market encourages farm gate sales. Despite the identified price differences between farm-get the price (home selling price) and the higher market prices yet, farmers depend highly on middlemen as a direct source of the market. [30] In a similar study conducted in Malawi found that farmers in the central region were more likely to sell their maize grains to private traders rather than local markets. Also, [31] in their study documented that, local/village maize assemblers are the main marketing route for smallholder farmers in their study areas. Ignoring the fact that, choices of marketing channel have a direct impact on the household income in the end because marketing cost varies based on marketing channels which differentiate household returns to investment.

This conclusion is being guided with a simple linear regression output which shows that, there is a significant variation of household income based on the choice of their marketing channels. [32] Reported similar findings that in Zambia farmers who sell their maize directly to grain processors receive an average of $\$$ US.08/ $\mathrm{kg}$ more than those that sell to assembly traders in the village. Furthermore, 52\% of the respondents depend highly on the middlemen as a source of price information, the rest $48 \%$ depends on their neighbours. Due to the fact that the majority of farmers lack market information i.e. who are buyers, where to find them, when and how. [33] drew similar conclusions that smallholders farmers don't have access to the market information including; selling prices, who are consumers, customer taste and preferences, market location, when to sell, 
competitive market environments and all necessary legislative issues. Basically, accessibility to maize market price information would have a direct impact in rising farmers bargaining power with intermediaries and household income as well. The contributions of maize marketing channels need to be well modelled considering its significant relationship with household income and return to investments.

Monthly maize price trends on the studied area for two cropping seasons consecutively have been collected to justify maize store time for each season. Results show that there are price differences between two cropping seasons. The 2016/17 season was found to be higher compared with 2017/18. Despite the economic theory assumptions that with an increase in commodities price large quantities will be offered to the market, yet, these results showed that there is no significant relationship between the quantity of maize sold in the household and the accessibility to price trends information. Hence, the quantity of maize sold by the households is driven by other factors rather than market prices. A study conducted in Zambia by [34] reported similar findings that, the majority of the surveyed households were found to have little/no positive responsiveness of maize market contribution to higher predictable maize prices. Additionally, [35, 36] documented similar findings that farmers' planting and marketing decisions are mostly driven by customary conduct and practices rather than price.

Nevertheless, most of the farmer's usually sale large volume of their maize stock soon after harvest with low prices, ignoring the fact that maize prices rise just few months after harvest to the point that smaller quantity of maize sales brings much cash. The situation is highly influenced by their desperation to cater for social obligations. Furthermore, during Focus Group Discussion farmer claims to have no power to dictate maize price. They were simply accepting prices given by village traders/assemblers. [37] In their study documented similar findings in which maize traders dominated the maize prices in the market. The local maize assemblers were the main marketing option for smallholder farmers in all the sites visited during the study.

\section{Conclusion}

This study revealed that, household can optimize income generated from maize investment for at least six months store-time. Therefore, maize store-time as a major aspect of Post-Harvest Loss need to be given much attention. Farmers should be well equipped with all necessary techniques on improving their store-time with the aim of gaining much profit taking advantage of price variability. This is based on the fact that, farmers opt for immediately postharvest sales despite its low price in order to meet their social obligations. In this study, PICS bag proved to be the most efficient improved storage structure/method with least contributions to maize postharvest losses throughout six months store-time, although it wasn't a dominant storage structure within a study area compared with polyethylene bags. In additionally, metal drums were found to be the second best storage structure throughout six months store-time when farmers followed proper maize drying chain before storage.

\section{Acknowledgements}

We acknowledge the African Development Bank (AfDB) through GRANT No. 2100155032816 and TAMASA Project under CIMMITY-Tanzania for their financial support through this study. Also Nelson Mandela Institution of Science and Technology for guidance and supervisions, we thank the District authorities in the study area and all those who were involved in data collection, analysis, and report compilation.

\section{References}

[1] Suleiman, R. A. and Rosentrater, K. A. (2015). Current Maize Production, Postharvest Losses and the Risk of Mycotoxins Contamination in Tanzania. In 2015 ASABE International Meeting (pp. 1-28).

https://doi.org/10.13031/aim.20152189434

[2] Amani, H. (2004). Agricultural development and food security in sub -Saharan Africa Tanzania Country report. Economic and Social Research Foundation (ESRF), (August). Retrieved from

http://www.sarpn.org/documents/d0001583/FAO2005_Casest udies_Tanzania.pdf

[3] URT-MAFC (2013). National Agriculture Policy Draft, Dares -Salaam, February 2013, 47, RetrievedfromHTTP://www.tzdpg.or.tz/fileadmin/documents/ dpg_internal/dpg_working_groups_clusters/cluster_1/agricult ure $/ 2$._Ag_policies_and_strategies/National_ag_policies/1._2 013_NATIONAL_AGRICULTURAL_POLICY

_FIN̄ALFebruari_2013.pdf

[4] Nyangito, H., 1997. A review of policies on the maize subsector in Kenya, Institute of Policy Analysis and Research, Nairobi, Kenya.

[5] Larsen, A. F., \& Lilleør, H. B. (2014). Beyond the field: The impact of farmer field schools on food security and poverty alleviation. World Development, 64, 843-859. https://doi.org/10.1016/j.worlddev.2014.07.003

[6] Kilima, F. T. M., Chung, C., Kenkel, P. Mbiha, E. R. (2008). Impacts of market reform on spatial volatility of maize prices in Tanzania. Journal of Agricultural Economics, 59 (2), 257270. https://doi.org/10.1111/j.1477 -9552.2007.00146.x

[7] Stephens, E. C. and Barrett, C. B. (2011). Incomplete credit markets and commodity marketing behaviour. Journal of Agricultural Economics 62 (1), 1-24. https://doi.org/10.1111/j.1477-9552.2010.00274.x

[8] Park, A. (2006). Risk and household grain management in developing countries. The Economic Journal 116 (514), 10881115. https://doi.org/10.1111/j.1468-0297.2006.01124.x

[9] Lowenberg-DeBoer, J., Abdoulaye, T. Kabore, D. (1994). The opportunity cost of capital for agriculture in the Sahel: Case study evidence from Niger and Burkina Faso (staff paper). West Lafayette, IN: Purdue University Department of Agricultural Economics. (94-2). 
[10] Katengeza, S., Mangisoni, J. H., Kassie, G. T., Sutcliffe, C., Langyintuo, A. S., La Rovere, R., \& Mwangi, W. M. (2012). Drivers of improved maize variety adoption in drought prone areas of Malawi. Journal of Development and Agricultural Economics, 4 (14), 393-403. doi: 10.5897/jdae12.029.

[11] Mason, N. M. and Smale, M. (2013). Impacts of subsidized hybrid seed on indicators of economic well - being among smallholder maize growers in Zambia. Agricultural Economics 44 (6), 659-670. https://doi.org/10.1111/agec.12080

[12] Bezu, S., Kassie, G. T., Shiferaw, B. Ricker-Gilbert, J. (2014). Impact of improved maize adoption on the welfare of farm households in Malawi: a panel data analysis. World Development 59, $120-131$. https://doi.org/10.1016/j.worlddev.2014.01.023

[13] Ricker-Gilbert, J. and Jones, M. (2015). Does storage technology affect adoption of improved maize varieties in Africa? Insights from Malawi's input subsidy program. Food $\begin{array}{llll}\text { policy } & 50, & 92 & -105 \text {. }\end{array}$ https://doi.org/10.1016/j.foodpol.2014.10.015

[14] Boxall, R. A. (2002). Damage and loss caused by the Larger Grain Borer Prostephanus truncatus. Integrated Pest Management Reviews 7 (2), 105-121 https://doi.org/10.1023/A:1026397115946

[15] FAO, (2015). The State of Food Insecurity in the World 348, Rome. Retrieved from (www.fao.org/publications).

[16] Brennan, M. J. (1958). The supply of storage. The American Economic Review, 48 (1), 50-72.

[17] Renkow, M. (1990). Household inventories and marketed surplus in semisubsistence agriculture. American Journal of Agricultural Economics 72 (3), 664-675.

[18] Saha, A. and Stroud, J. (1994). A household model of on-farm storage under price risk. American Journal of Agricultural Economics 76 (3), 522-534.

[19] Zuur, A. F., Ieno, E. N., Elphick, C. S. (2010) A protocol for data exploration to avoid common statistical problems, Methods in ecology and evolution 1 (1), 3-14.

[20] Swai, J., Mbega, E. R., Mushongi, A., Ndakidemi, P. A. (2019). Post-harvest losses in maize store-time and marketing model perspectives in Sub-Saharan Africa. Journal of Stored Products and Postharvest Research, 10 (1), 1-12.

[21] Bywaters, D. and Mlodkowski, P. (2012). The role of transactions costs in economic growth. The International Journal of Economic Policy Studies 7: 53-66.

[22] Thirtle, Colin, Lin Lin, and Jenifer Piesse (2003) "The impact of research-led agricultural productivity growth on poverty reduction in Africa, Asia and Latin America." World Development 31.12 (2003): 1959-1975.

[23] Miller, D. J. and Hayenga, M. L. (2001). Price cycles and asymmetric price transmission in the U.S. pork market. American Journal of Agricultural Economics 83 (3), 551-562. https://doi.org/10.1111/0002 -9092.00177

[24] Udoh, J. M., Cardwell, K. F. Ikotun, T. (2000). Storage structures and aflatoxin content of maize in five agroecological zones of Nigeria. Journal of Stored Products Research, 36 (2), 187-201. https://doi.org/10.1016/S0022-

\section{X(99)00042-9.}

[25] Thamaga-Chitja, J. M., Hendriks, S. L., Ortmann, G. F. Green, M. (2004). Impact of maize storage on rural household food security in Northern KwaZulu-Natal. Journal of Consumer Sciences 32 https://www.ajol.info/index.php/jfecs/article/viewFile/52843/4 1445

[26] Baoua, I. B., Margam, V., Amadou, L. Murdock, L. L. (2012). Performance of triple bagging hermetic technology for postharvest storage of cowpea grain in Niger. Journal of Stored Products Research 51, 81-85. https://doi.org/10.1016/j.jspr.2012.07.003

[27] Kherallah, M. and Kirsten, J. F. (2002). The New Institutional Economics: Applications For Agricultural Policy Research In Developing Countries. Agrekon, 41 (2), 110-133.

[28] Makhura, M. T. (2001). Overcoming transaction costs barriers to market participation of smallholder farmers in the Northern Province of South Africa (Doctoral dissertation, University of Pretoria).

[29] Mmbando, F. E., Wale, E., Baiyegunhi, L. J. S. Darroch, M. A. G. (2016). The choice of marketing channel by maize and pigeonpea smallholder farmers: evidence from the northern and eastern zones of Tanzania. Agrekon, 55 (3), 254-277.

[30] Chirwa, E. W. 2009. Determinants of marketing channels among smallholder maize farmers In Malawi. Department of Economics, University of Malawi. Working Paper No. 2009/03.

[31] Jayne, T. S., Mather, D., and Mghenyi, E. (2010). Principal challenges confronting smallholder agriculture in Sub-Saharan Africa. World development, 38 (10), 1384-1398 doi: 10.1016/j.worlddev.2010.06.002.

[32] Sitko, N. J. and Jayne, T. S. (2014). Exploitative briefcase businessmen, parasites, and other myths and legends: assembly traders and the performance of maize markets in eastern and southern Africa, World Development. 54: 56-67. http://dx.doi.org/10.1016/j.worlddev.2013.07.008

[33] Azam, M. S., Imai, K. S. Gaiha, R. (2012). Agricultural supply response and smallholders market participation-the case of Cambodia. Kobe, University Japan.

[34] Mather, D., Boughton, D. Jayne, T. S. (2013). Explaining smallholder maize marketing in southern and eastern Africa: The roles of market access, technology and household resource endowments. Food Policy 43, 248-266. https://doi.org/10.1016/j.foodpol.2013.09.008

[35] Mathur, P. N. and Ezekiel, H. (1961). Marketable surplus of food and price fluctuations in a developing economy. Kyklos 14 (3), 396-408. https://doi.org/10.1111/j.14676435.1961.tb00360.x

[36] Enke, S. (1963). Economics for development. Prentice-Hall.

[37] Mvula, P. M., Chirwa, E. W. Kadzandira, J. (2003). Poverty and Social Impact Assessment in Malawi: Closure of ADMARC Markets. Draft Final Report submitted to Social Development Department, World Bank and Economic Section/PRSP Support, GTZ. 